\title{
Recovery of MC-LR in Fish Liver Tissue
}

\author{
Bernhard Ernst, Lisa Dietz, Stefan J. Hoeger, Daniel R. Dietrich \\ Environmental Toxicology, University of Konstanz, P.O. Box X-918, \\ D-78457 Konstanz, Germany
}

\begin{abstract}
Cyanotoxins, particularly microcystins (MCs), have been shown to be a hazard to human health. MCs accumulate in aquatic organisms probably as a result of irreversible binding to liver protein phosphatases. The aim of this study was to describe the recovery of MC from fish liver using various detection methods, with MC-LR as the representative congener. These findings are discussed in conjunction with the current procedures and limit values used for human risk assessment. Following incubation of liver homogenates with various MC-LR concentrations, the homogenates were extracted by a water/ methanol/butanol mixture via different treatments and subsequently analyzed via the colorimetric protein phosphatase inhibition assay (cPPA), HPLC, and anti-Adda ELISA. Detection via cPPA appeared to yield the highest recovery of MC-LR, although the presence of unspecific background may have resulted in overestimation of the true recovery. The recoveries determined via HPLC and anti-Adda ELISA were comparable to each other. The limits of detection were $0.01-2.4 \mu \mathrm{g} \mathrm{MC}-\mathrm{LR} / \mathrm{g}$ liver tissue, depending on the method used. Maximum MC-LR recovery from samples incubated with 10 and $100 \mu \mathrm{g} \mathrm{MC}-\mathrm{LR} / \mathrm{g}$ ranged between $44 \%$ and $101 \%$. Recovery from samples incubated with $1 \mu \mathrm{g} \mathrm{MC}-\mathrm{LR} / \mathrm{g}$ liver tissue was below $3 \%$. Lower recovery is assumed to result from irreversible, covalent MC protein binding, as confirmed by Western blotting of liver homogenates with anti-Adda immunoprobing. The results demonstrate that further investigation of and improvement in routinely applied MC methods for fish tissue and/or food analyses are needed for a reliable risk assessment.
\end{abstract}

Keywords: microcystin; recovery; fish; tissue; risk assessment; cyanobacteria; liver

\section{INTRODUCTION}

Cyanobacteria occur worldwide in coastal and surface waters. To date, at least 46 cyanobacterial species have been shown to produce potent hepato- and/or neurotoxins. Approximately $75 \%$ of water samples containing cyanobacteria also contain toxic cyanobacterial metabolites (Sivonen and Jones, 1999).

Correspondence to: D. R. Dietrich; e-mail: Daniel.Dietrich@ uni-konstanz.de

Contract grant sponsor (in part): Arthur and Aenne Feindt Foundation (Germany).

Contract grant sponsor (in part): European Union.

Contract grant number: PEPCY QLRT-2001-02634.
The most widespread cyanobacterial toxins are the microcystins (MC) and the related nodularins. These cyclic peptides are produced mainly by the cyanobacterial genera Anabaena, Anabaenopsis, Microcystis, Oscillatoria, and Nostoc. So far, nearly 80 variants of microcystins have been identified (Dietrich and Hoeger, 2005), which are responsible for the deaths of terrestrial wildlife, livestock (Briand et al., 2003), and fish (Landsberg, 2002) all over the world.

Human injury, that is, liver necrosis and acute diarrhea/ gastroenteritis after acute exposure to microcystins (Byth, 1980; Turner et al., 1990; Teixeira et al., 1993; Pouria et al., 1998; Annadotter et al., 2001) and an increased incidence of primary liver or colorectal cancer after chronic exposure (Yu, 1995; Zhou et al., 2002) have been reported. This highlights the need to consider the acute and chronic effects of microcystin exposure via nutritional intake, including water, especially as human deaths have been 
associated with, but not proven to result from, the consumption of drinking water or food contaminated with cyanobacterial toxins (Chorus et al., 2000; Falconer, 2001; Dietrich and Hoeger, 2005). Indeed, the World Health Organization (WHO) has recommended a provisional guideline of a maximum microcystin concentration of $1.0 \mu \mathrm{g} \mathrm{MC-LR/L} \mathrm{final}$ drinking water. In this regard, it was assumed that most of the microcystin ingested daily came from contaminated drinking water $(80 \%)$. However, other sources of oral microcystin exposure exist, for example, contaminated food, uptake during recreational activity, and self-inflicted exposure via cyanobacterial food supplements (Dietrich and Hoeger, 2005).

Microcystins have been shown to accumulate in various aquatic organisms including mussels (Williams et al., 1997c; Karlsson et al., 2003a), crustaceans (Liras et al., 1998; Kankaanpää et al., 2005), and fish (Williams et al., 1997a; Sipiä et al., 2001a; Kankaanpää et al., 2002a; Karlsson et al., 2003b; Soares et al., 2004). The microcystin concentrations detected in field samples of aquatic organisms varied between 0.01 and $100 \mu \mathrm{g} / \mathrm{g}$ tissue (Williams et al., 1997b, 1997c; Magalhaes et al., 2001, 2003; Mohamed et al., 2003). Most MCs accumulate in the liver because of the first-pass effect; however, sufficient MCs can pass via the liver to other organs including muscle, kidney, and brain (Williams et al., 1997a; Fischer and Dietrich, 2000).

For detection, microcystins are routinely extracted from animal tissue by freezing/thawing or sonication using methanol or a mixture of water/methanol/butanol (water/MeOH/ $\mathrm{BuOH}$ ) as extraction solvent (Eriksson et al., 1989; Prepas et al., 1997; Amorim and Vasconcelos, 1999; Sipiä et al., 2001b; Kankaanpää et al., 2002b; Mohamed et al., 2003). Microcystins are routinely detected in the resulting tissue extracts via HPLC-UV (Eriksson et al., 1989; Andersen et al., 1993; Lawrence and Menard, 2001; Magalhaes et al., 2001), colorimetric (cPPA), or radioactive protein phosphatase inhibition assay (Andersen et al., 1993; Williams et al., 1995, 1997c; Prepas et al., 1997; Tencalla and Dietrich, 1997; Malbrouck et al., 2003, 2004), or ELISA (Amorim and Vasconcelos, 1999; Sipiä et al., 2001b; Magalhaes et al., 2001, 2003). However, discussion on the applicability and quality of these analytical methods is ongoing, as microcystins are at least partly covalently bound to PPs, and therefore the microcystin concentrations reported in tissue samples may reflect only freely available microcystins (Meriluoto, 1997; Dietrich and Hoeger, 2005).

The aim of this study was to compare different microcystin detection methods, sample pretreatments, and extraction steps in order to determine the most reliable method or methods for routine determination of microcystin concentrations in fish tissue. These findings are discussed in conjunction with the currently employed human risk assessment procedures and limit values for contaminated foodstuffs (e.g., fish).

\section{MATERIALS AND METHODS}

\section{Sample Preparation and MC-LR Incubation}

Double-distilled water was purified to $18.2 \mathrm{M} \Omega \mathrm{cm}$ using a Milli-Q system (Millipore, Germany). All other chemicals were of the highest analytical grade commercially available. Microcystin-LR was obtained from Alexis (Switzerland).

Rainbow trout (Oncorhynchus mykiss) were obtained from a local fish hatchery (250-300 g/fish). The fish were killed with a blow to the head, and the livers (2-4 g/fish) were removed, weighed, pooled, and placed in a sample buffer (10 mL of buffer/g tissue) containing $10 \mathrm{mM}$ Tris $\mathrm{HCl}, 140 \mathrm{mM} \mathrm{NaCl}, 5 \mathrm{mM}$ EDTA, Triton X-100 (1\%), $1 \mathrm{mM}$ PMSF, and $1 \mathrm{mM}$ DTT. Tissue was minced using an Ultra Turrax T25 (Janke \& Kunkel, Germany) and homogenized using a Dounce Homogenizer 3431-E20 (Thomas Technological Service, USA).

Each homogenate was divided into aliquots, one of which served as a control. Homogenates were incubated with 1,10 , and $100 \mu \mathrm{g}$ MC-LR/g tissue (Table I). MC-LR incubation took place in continuously rotating glass vials at $30^{\circ} \mathrm{C}$ for $20 \mathrm{~h}$ in order to achieve a representative amount of covalently bound microcystin complexes (Craig et al., 1996). Four or five different homogenates of pooled liver samples were used for each MC-LR concentration (Table I). Controls and MC-LR samples were handled identically.

\section{Sample Splitting and Extraction}

All liver homogenate aliquots (samples), incubated for $20 \mathrm{~h}$ with or without MC-LR, were divided into 3 subsamples after incubation. The first subsample was stored at $-20^{\circ} \mathrm{C}$ until use for SDS-PAGE/Western blotting. The second subsample was centrifuged $(15,000 \times \mathrm{g})$ for $20 \mathrm{~min}$ at $4{ }^{\circ} \mathrm{C}$. The supernatant (treatment $\mathrm{S}$ ) obtained was stored at $-20^{\circ} \mathrm{C}$ until further cleanup steps prior to $\mathrm{MC}$ analyses. The remaining pellet (treatment $\mathrm{P}$ ) and subsample 3 (treatment E) were subsequently subjected individually to a single MC-LR extraction (Fig. 1). Extraction was performed using a 75:20:5 (v/v/v) mixture of water/methanol/butanol, which has been demonstrated to yield the best possible extraction (Kankaanpää et al., 2002b). The extraction involved alternate shaking and ultrasonication at $35 \mathrm{kHz}$ at hourly intervals over an 8-h period. Extracts were centrifuged $(20 \mathrm{~min}$ at $15,000 \times \mathrm{g}$ ), and the resulting supernatants were stored at $-20^{\circ} \mathrm{C}$ for further cleanup steps prior to microcystin analysis (Fig. 1).

\section{Analytical Subsample Pretreatment and Microcystin Analysis}

Prior to microcystin analysis, all three subsample pretreatment types ( $\mathrm{S}, \mathrm{P}$, and $\mathrm{E}$ ) were purified and concentrated 
TABLE I. Experimental setup with incubated fish liver weights and MC-LR quantities applied

\begin{tabular}{lccccc}
\hline $\begin{array}{l}\text { Incubation } \\
{[\mu \mathrm{g} \text { MC-LR/g }} \\
\text { tissue] }\end{array}$ & $\begin{array}{c}\text { Quantity of } \\
\text { Incubated } \\
\text { Liver }[\mathrm{g}]\end{array}$ & $\begin{array}{c}\text { MC-LR Added } \\
{[\mu \mathrm{g}]}\end{array}$ & $\begin{array}{c}\text { Volume of } \\
\text { Resuspension } \\
{[\mathrm{mL}]}\end{array}$ & $\begin{array}{c}\text { Theoretical } \\
\text { Concentration on } \\
\text { Column/Assay } \\
{[\mu \mathrm{g} \text { MC-LR/mL] }}\end{array}$ & $\begin{array}{c}\text { Number of } \\
\text { Incubations/Controls }\end{array}$ \\
\hline Control & $0.2-1$ & 0 & 1 & 0 & 5 \\
1 & $1,2.5$ & $1,2.5$ & $1,0.5$ & 1,5 & 4 \\
10 & 0.5 & 5 & 1 & 5 & 4 \\
100 & 0.2 & 20 & 1 & 20 & 5 \\
\hline
\end{tabular}

using C18 end-capped solid-phase extraction (SPE) cartridges (Chromabond C18ec, 500 mg; Macherey-Nagel, Germany). For SPE, samples were diluted with water to give methanol concentrations of $<5 \%$. The cartridges were preconditioned using $9 \mathrm{~mL}$ of $100 \%$ methanol, followed by $9 \mathrm{~mL}$ of water. Samples were applied to the cartridges slowly, followed by two washing steps using $9 \mathrm{~mL}$ of MQ and $9 \mathrm{~mL}$ of $10 \%$ methanol. Samples were then eluted from the solid phase in the cartridge using $12 \mathrm{~mL}$ of $100 \%$ methanol, and the eluents were dried under a nitrogen stream and finally resuspended in $20 \%$ methanol (Table I) to give the final treatment type-specific microcystin analytes (MC analytes; Fig. 1), which were stored at $-20^{\circ} \mathrm{C}$ until microcystin analysis.

The colorimetric protein phosphatase assay (cPPA) with 4-nitrophenylphosphate (Acros Organics, Belgium) as substrate was performed as described by Heresztyn and Nicholson (2001), using recombinant protein phosphatase 1

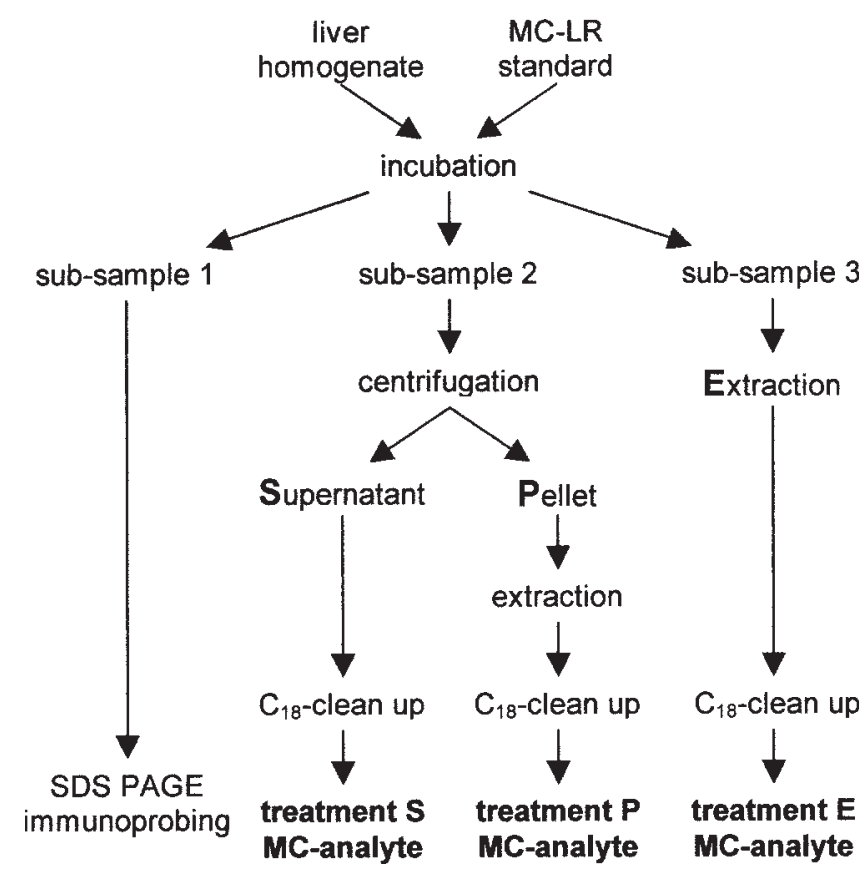

Fig. 1. Experimental setup: scheme of sample aliquots, subsample extraction, and pretreatment. from E. coli (New England BioLabs Inc., UK) at an end concentration of 0.375 units/mL with MC-LR as a standard. The PP-inhibiting capacities of the respective MC analytes were compared to an MC-LR standard curve in the same assay. The detection range (20\%-80\% inhibition of PP1) of the colorimetric PPA used was 1.5-15 $\mu \mathrm{g}$ MC-LR/L, with a derived $\mathrm{IC}_{50}$ of $4.8 \mu \mathrm{g}$ MC-LR/L. Enzyme solution $(20 \mu \mathrm{L} /$ well) was added to $20 \mu \mathrm{L}$ of sample in 96-well plates and incubated at $37^{\circ} \mathrm{C}$ for $5 \mathrm{~min}$. Substrate solution $(200 \mu \mathrm{L} /$ well) was added and incubated at $37^{\circ} \mathrm{C}$ for $2 \mathrm{~h}$, and the absorption was measured at $405 \mathrm{~nm}$ using an SLT Reader. The absorption was measured before and after incubation, and substrate conversion was determined as the difference between the first and second measurements. MC concentrations were calculated via comparison with substrate conversion of the MC-LR standards. Each MC analyte was analyzed 3 times in duplicate.

The anti-Adda ELISA Kit (Abraxis LLC, USA) employed in the tests is based on an antiserum raised against the unique $\mathrm{C}_{20}$ amino acid 3-amino-9-methoxy2,6,8-trimethyl-10-phenyl-4,6-decadieonic acid (Adda; Fischer et al., 2001). The ELISA was performed according to the manufacturer's instructions. Each MC analyte was analyzed 3 times in duplicate.

HPLC was performed using Beckman (Germany) HPLC equipment (Autosampler 507e, Solvent Module 125) with an analytical $\mathrm{C}_{18}$ column (Grom-Sil 120 ODS-4 HE, $5 \mu \mathrm{m}$, $250 \times 4 \mathrm{~mm})$. A gradient with water $(0.05 \%$ TFA) and acetonitrile $(0.05 \%$ TFA) as the mobile phase was used according to the method described by Lawton et al. (1994). MCLR was detected using a photodiode array SPD-M10A VP (Shimadzu, Germany) and identified via retention time and typical spectrum in comparison with internal MC-LR standards. MC-LR concentrations were calculated using peak area and peak height. HPLC MC-LR analysis was carried out once for each MC-LR analyte.

For qualitative detection of covalently bound microcystin adducts, subsamples 1 (Fig. 1) were separated via 10\% SDS PAGE in accordance with Laemmli (1970). The protein content of each treatment was determined according to the method of Bradford (1976) and adjusted to give a protein load of $60 \mu \mathrm{g}$ protein/lane. Separated proteins were transferred onto a nitrocellulose membrane via Western 
blot. The membranes were blocked using TTBS $+1 \%$ BSA for $30 \mathrm{~min}$, and MC-LR adducts were detected via incubation with polyclonal sheep anti-Adda serum (diluted 1:1000 in blocking buffer) at room temperature for $1 \mathrm{~h}$ according to Fischer and Dietrich (2000). Membranes were washed using TTBS $(3 \times 5 \mathrm{~min})$ and incubated with secondary antibody (antisheep IgG-AP, diluted 1:5000 in TTBS; SigmaAldrich, Germany) at room temperature for $1 \mathrm{~h}$. After washing with TTBS $(3 \times 5 \mathrm{~min})$ and TBS $(1 \times 15 \mathrm{~min})$, specific bands were finally stained using Sigma Fast Red ${ }^{\mathbb{R}}$ (Sigma-Aldrich, Germany) according to the manufacturer's instructions. The molecular weights of detected adducts were estimated by comparison with full-range rainbow marker proteins RPN 800 (Amersham, UK).

\section{Statistics}

Data analyses were carried out using JMP $^{\circledR}$ (USA) software. Values represent the mean \pm SD of at least three separate experiments. Results of the HPLC, ELISA, and PPA analyses, as well as results of different treatments, were analyzed for statistical differences using analysis of variance (ANOVA) and the Tukey-Kramer multiple comparisons test $(p \geq 0.05)$. The sum of MC-LR concentrations analyzed in analyte samples of treatments $\mathrm{S}$ and $\mathrm{P}(\mathrm{S}+\mathrm{P})$ were tested for statistical differences $(p \geq 0.05)$ to concentrations analyzed via treatment E using the Student's $t$ test.

\section{RESULTS}

All MC analytes were analyzed by cPPA, HPLC, and antiAdda ELISA. Detected MC-LR concentrations in the respective analytes and their corresponding deduced tissue concentrations and recoveries are shown in Tables II-IV. Analyte samples of treatment $\mathrm{S}$ were analyzed for quantification of soluble MC-LR. Samples of treatment P were analyzed to recover the remaining, extractable, and not readily soluble MC-LR. Analyte samples of treatment E were analyzed to quantify the overall extractable MC-LR in the incubated tissue homogenates.

In all treatment approaches, the sum of MC-LR concentrations analyzed in the $\mathrm{S}+\mathrm{P}$ analyte samples were not significantly different from recovery from whole tissue homogenate extraction (treatment E), regardless of the MC-LR concentration and detection methods used. The highest MC-LR recovery generally was achieved using whole-tissue homogenate extraction (treatment E) without previous centrifugation and separation (Tables II-IV). However, the overall extractable MC-LR analyzed by treatment E did not always differ significantly from the quantities of soluble MC-LR in treatment $\mathrm{S}$.

When comparing the different detection methods, determinations by HPLC and ELISA yielded comparable MCLR recoveries in all MC-LR concentrations and sample treatments applied. Analyses with cPPA generally resulted in higher recovery than detection via either HPLC or ELISA (Tables II-IV), although this was not significant at all MC-LR concentration levels (1, 10, and $100 \mu \mathrm{g} / \mathrm{g})$ used.

Analyses of controls via cPPA resulted in an average background noise equivalent to $0.3-0.4 \mu \mathrm{g}$ MC-LR/mL analyte (Table II). Nonspecific positive signals were also observed with the anti-Adda ELISA and control sample analytes (Table IV). This background noise, however, corresponded to $\leq 0.01 \mu \mathrm{g} \mathrm{MC}-\mathrm{LR} / \mathrm{mL}$ analyte and therefore

TABLE II. MC-LR concentrations detected, corresponding tissue concentrations, and calculated recovery after a 20-h incubation of fish liver tissue with various MC-LR concentrations using different sample treatments (Fig. 1) with the colorimetric protein phosphatase inhibition assay (cPPA) as the analytical method

\begin{tabular}{|c|c|c|c|c|c|}
\hline & & \multicolumn{4}{|c|}{ PPA } \\
\hline \multicolumn{2}{|c|}{$\begin{array}{l}\text { Incubation } \\
(\mu \mathrm{g} \text { MC-LR/g) }\end{array}$} & $\begin{array}{c}\text { Detected } \\
\text { Concentration } \\
(\mu \mathrm{g} / \mathrm{mL})\end{array}$ & $\begin{array}{l}\text { Detected Tissue } \\
\text { Concentration } \\
(\mu \mathrm{g} / \mathrm{g})\end{array}$ & Recovery (\%) & $\begin{array}{c}\text { Number of } \\
\text { Incubations } \\
\text { Analyzed }\end{array}$ \\
\hline \multirow[t]{4}{*}{ S } & Control & $0.27 \pm 0.212$ & & & 4 \\
\hline & 1 & i.d. & i.d. & i.d. & 3 \\
\hline & 10 & $3.51 \pm 0.511$ & $7.02 \pm 1.022$ & $70 \pm 10.2$ & 3 \\
\hline & 100 & $14.19 \pm 2.793$ & $70.95 \pm 13.96$ & $71 \pm 13.9$ & 4 \\
\hline \multirow[t]{4}{*}{$\mathrm{P}$} & Control & $0.38 \pm 0.415$ & & & 4 \\
\hline & 1 & i.d. & i.d. & i.d. & 3 \\
\hline & 10 & $1.21 \pm 0.298$ & $2.42 \pm 0.596$ & $24 \pm 05.9$ & 3 \\
\hline & 100 & $1.89 \pm 0.964$ & $9.45 \pm 4.820$ & $9 \pm 04.8$ & 3 \\
\hline \multirow[t]{4}{*}{$\mathrm{E}$} & Control & $0.39 \pm 0.219$ & & & 4 \\
\hline & 1 & i.d. & i.d. & i.d. & 3 \\
\hline & 10 & $5.05 \pm 1.288$ & $10.10 \pm 2.576$ & $101 \pm 25.8$ & 4 \\
\hline & 100 & $18.59 \pm 5.593$ & $92.95 \pm 27.96$ & $93 \pm 28.0$ & 3 \\
\hline
\end{tabular}

i.d. = indistinguishable from controls. 
TABLE III. MC-LR concentrations detected, corresponding tissue concentrations, and calculated recovery after a 20-h incubation of fish liver tissue with various MC-LR concentrations using different sample treatments (Fig. 1) with high-performance liquid chromatography as the analytical method

\begin{tabular}{|c|c|c|c|c|c|}
\hline & & \multicolumn{4}{|c|}{ HPLC } \\
\hline \multicolumn{2}{|c|}{$\begin{array}{l}\text { Incubation } \\
(\mu \mathrm{g} \text { MC-LR/g) }\end{array}$} & $\begin{array}{c}\text { Detected } \\
\text { Concentration } \\
(\mu \mathrm{g} / \mathrm{mL})\end{array}$ & $\begin{array}{l}\text { Detected Tissue } \\
\text { Concentration } \\
(\mu \mathrm{g} / \mathrm{g})\end{array}$ & Recovery (\%) & $\begin{array}{c}\text { Number of } \\
\text { Incubations } \\
\text { Analyzed }\end{array}$ \\
\hline \multirow[t]{4}{*}{ S } & Control & nd & & & 3 \\
\hline & 1 & nd & nd & nd & 3 \\
\hline & 10 & $2.25 \pm 0.31$ & $4.5 \pm 0.60$ & $45 \pm 06.2$ & 3 \\
\hline & 100 & $12.63 \pm 1.66$ & $63.2 \pm 8.30$ & $63 \pm 08.3$ & 4 \\
\hline \multirow[t]{4}{*}{$\mathrm{P}$} & Control & nd & & & 3 \\
\hline & 1 & nd & nd & nd & 3 \\
\hline & 10 & $0.21 \pm 0.11$ & $0.4 \pm 0.22$ & $4 \pm 02.2$ & 3 \\
\hline & 100 & $1.03 \pm 0.50$ & $5.2 \pm 2.50$ & $5 \pm 02.5$ & 4 \\
\hline \multirow[t]{4}{*}{$\mathrm{E}$} & Control & nd & & & 3 \\
\hline & 1 & nd & nd & nd & 3 \\
\hline & 10 & $2.19 \pm 0.50$ & $4.4 \pm 1.00$ & $44 \pm 10.0$ & 4 \\
\hline & 100 & $16.10 \pm 1.37$ & $80.5 \pm 6.85$ & $81 \pm 06.8$ & 4 \\
\hline
\end{tabular}

nd, not detectable.

was at least 30 times lower than the background observed in the cPPA analyses. Conversely, no background noise relevant to the MC-LR peak retention time was observed in the HPLC analyses. To compare the results obtained with the three methods of MC analysis, concentrations detected via CPPA and ELISA were corrected for nonspecific background noise (subtraction of the background noise from the raw value in the analysis).

Limits of detection for MC-LR in the liver homogenate samples used in this study were $1.2 \mu \mathrm{g}$ MC-LR/mL (cPPA, Table II), $0.2 \mu \mathrm{g}$ MC-LR/mL (HPLC, Table III), and
$0.01 \mu \mathrm{g} \mathrm{MC-LR/mL} \mathrm{(anti-Adda} \mathrm{ELISA,} \mathrm{Table} \mathrm{IV).} \mathrm{These}$ detection limits translate to minimum MC-LR tissue concentrations of $2.4 \mu \mathrm{g}$ MC-LR/g for cPPA (Table II), $0.4 \mu \mathrm{g}$ MC-LR/g for HPLC (Table III), and $0.01 \mu \mathrm{g} \mathrm{MC-LR/g} \mathrm{for}$ anti-Adda ELISA (Table IV).

Maximum MC-LR recovery from liver homogenate samples incubated with 10 and $100 \mu \mathrm{g} \mathrm{MC-LR/g,} \mathrm{for} \mathrm{exam-}$ ple, for treatment $\mathrm{E}$ (whole homogenate extract), ranged between $44 \%$ and $101 \%$, depending on the initial MC-LR concentration and detection method used (Tables II-IV). The reliability of the recovery data (the variance) largely

TABLE IV. MC-LR concentrations detected, corresponding tissue concentrations, and calculated recovery after a 20-h incubation of fish liver tissue with various MC-LR concentrations using different sample treatments (Fig. 1) with anti-Adda-ELISA as the analytical method

\begin{tabular}{|c|c|c|c|c|c|}
\hline & & \multicolumn{4}{|c|}{ ELISA } \\
\hline \multicolumn{2}{|c|}{$\begin{array}{l}\text { Incubation } \\
(\mu \mathrm{g} M C-L R / g)\end{array}$} & $\begin{array}{c}\text { Detected } \\
\text { Concentration } \\
(\mu \mathrm{g} / \mathrm{mL})\end{array}$ & $\begin{array}{c}\text { Detected Tissue } \\
\text { Concentration } \\
(\mu \mathrm{g} / \mathrm{g})\end{array}$ & Recovery (\%) & $\begin{array}{c}\text { Number of } \\
\text { Incubations } \\
\text { Analyzed }\end{array}$ \\
\hline \multirow[t]{4}{*}{$S$} & Control & $<0.01$ & & & 3 \\
\hline & 1 & $0.01 \pm 0.003$ & $0.01 \pm 0.003$ & $1 \pm 00.3$ & 3 \\
\hline & 10 & $2.33 \pm 0.116$ & $4.66 \pm 0.232$ & $47 \pm 02.3$ & 3 \\
\hline & 100 & $10.42 \pm 2.009$ & $52.10 \pm 10.05$ & $52 \pm 10.1$ & 3 \\
\hline \multirow[t]{4}{*}{$\mathrm{P}$} & Control & $<0.01$ & & & 3 \\
\hline & 1 & $0.02 \pm 0.006$ & $0.02 \pm 0.006$ & $2 \pm 00.6$ & 3 \\
\hline & 10 & $0.37 \pm 0.135$ & $0.74 \pm 0.270$ & $7 \pm 02.7$ & 3 \\
\hline & 100 & $0.99 \pm 0.247$ & $4.95 \pm 1.235$ & $5 \pm 01.2$ & 3 \\
\hline \multirow[t]{4}{*}{$\mathrm{E}$} & Control & $0.01 \pm 0.005$ & & & 3 \\
\hline & 1 & $0.03 \pm 0.013$ & $0.03 \pm 0.013$ & $3 \pm 01.3$ & 3 \\
\hline & 10 & $2.89 \pm 0.536$ & $5.78 \pm 1.072$ & $58 \pm 10.7$ & 3 \\
\hline & 100 & $13.49 \pm 0.352$ & $67.45 \pm 1.760$ & $68 \pm 01.8$ & 3 \\
\hline
\end{tabular}




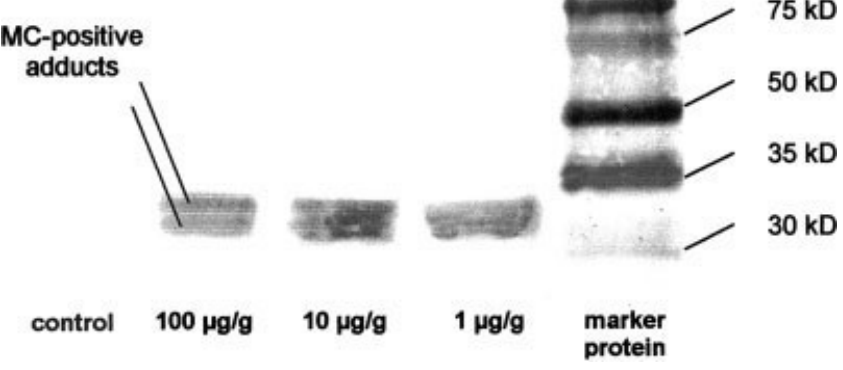

Fig. 2. Immunostaining of MC-LR adducts in fish liver homogenates following a $20-\mathrm{h}$ incubation with 1,10 , and $100 \mu \mathrm{g} \mathrm{MC}-\mathrm{LR} / \mathrm{g}$ tissue. Molecular weights were estimated via comparison with marker proteins.

depended, however, on the analytical method used. The analytical methods ranked in order from worst to best are: cPPA $<$ HPLC $<$ anti-Adda ELISA.

In contrast, MC-LR recovery from samples incubated with $1 \mu \mathrm{g} \mathrm{MC}-\mathrm{LR} / \mathrm{g}$ liver tissue was extremely low (1\%$3 \%$, even after water/ $\mathrm{MeOH} / \mathrm{BuOH}$ extraction. Indeed, anti-Adda ELISA analyses provided a detectable MC-LR concentration of only $0.01-0.03 \mu \mathrm{g}$ MC-LR/g liver tissue, depending on the sample pretreatment used (Table IV). As a result of having a higher limit of detection, neither the cPPA (Table II) nor the HPLC-PDA (Table III) analysis was able to detect MC-LR in the $1 \mu \mathrm{g} / \mathrm{g}$ liver homogenate samples.

Western blot analysis showed that anti-Adda immunostaining of positive protein adducts $(30-35 \mathrm{kD})$ could be detected in all liver homogenate samples incubated with MC-LR (1, 10, and $100 \mu \mathrm{g} / \mathrm{g}$ liver; Fig. 2).

\section{DISCUSSION}

The results demonstrated varying levels of MC-LR recovery from fish liver homogenates, depending on the treatment of the homogenate subsamples and the detection method used. Comparing recovery resulting from different subsample treatments, whole-tissue homogenate extraction provided comparable MC-LR recovery to the sum of recoveries of treatments $\mathrm{S}$ and $\mathrm{P}(\mathrm{E}=\mathrm{S}+\mathrm{P})$. This suggests that water/MeOH/BuOH extraction increases MC-LR recovery from incubated liver tissue. However, as the overall extractable MC-LR analyzed in treatment E samples did not always differ significantly from those of soluble MC-LR in treatment $\mathrm{S}$, the additional MC-LR recovery achieved by homogenate water/MeOH/BuOH extraction appears to be limited. For example, water/MeOH/BuOH extraction is not useful for extracting covalent bond MC.

Indeed, repetition of the extraction procedure resulted in no additional MC-LR recovery (data not shown). These findings are in agreement with those of Kankaanpää et al. (2002b), who demonstrated that extraction of nodularin from animal tissue yielded the best extraction results (highest recovery) using water/ $\mathrm{MeOH} / \mathrm{BuOH}$ 75:20:5 ( $/ v / v)$ with an 8-h extraction time and that extraction repetition did not improve recovery. On the contrary, repetitious extraction increased the amount of matrix compounds interfering with HPLC analysis of nodularin.

MC-LR recovery detected by CPPA was generally higher than that determined by anti-Adda ELISA or HPLC, independent of subsample treatment and the amount of MC-LR used for incubation of the homogenate. This is most likely a result of the high background of non-MC-LR-related PP inhibition, as strongly suggested by the PP inhibition observed in the controls. It is assumed that this high background of non-MC-LR-related PP inhibition may be the result of (i) specific endogenous PP1 inhibitors (Oliver and Shenolikar, 1998) in the liver homogenates liberated during the liver homogenization process and/or (ii) unspecific influences arising from matrix effects. These observations were corroborated by the findings of Sipiä et al. (2001a), who demonstrated that nodularin could not be detected in the muscle of Atlantic salmon via MC-LR ELISA, whereas analysis by cPPA resulted in 55-65 ng NOD/g. Sipiä et al. (2001a) also concluded that the disparate findings between the analyses by MC-LR ELISA and by cPPA were the result of turbidity and color as well as of matrix-interfering compounds in the tissue homogenates and the resulting extracts.

Consequently, this unspecific PP inhibition causes an overestimation of the $\mathrm{MC}$ and nodularin contamination in tissues in general and of MC-LR contamination in fish liver homogenates specifically, as presented in this study. Therefore, cPPA with PP1 appears inappropriate for routine MC and nodularin detection in tissue samples.

In contrast to cPPA detection, overall MC-LR recovery from liver homogenates determined by HPLC was comparable to that determined by anti-Adda ELISA. However, no MC-LR was detectable by HPLC in homogenates incubated with $1 \mu \mathrm{g}$ MC-LR/g, whereas the analysis with anti-Adda ELISA resulted in detectable MC-LR concentrations of up to $0.03 \mu \mathrm{g} / \mathrm{mL}$ analyte.

Similar observations were made by Kankaanpää et al. (2002a), who demonstrated that no nodularin was detectable via HPLC analysis in liver tissue from sea-trout, orally dosed with nodularin; in contrast MC-LR ELISA analysis resulted in nodularin concentrations of up to $1.2 \mu \mathrm{g} / \mathrm{g}$ tissue. These concentrations exceeded the detection limit for nodularin quantification in liver tissue $(0.15 \mu \mathrm{g} N O D / g)$ of the chromatographic system employed and thus should actually have been detectable via HPLC. Kankaanpää and co-authors concluded, in accord with Metcalf et al. (2000), that the discrepancy between HPLC and ELISA analyses is most likely a result of the detection of additional nodularin conjugates via the ELISA assay, whereas these conjugates would not be readily detectable via HPLC.

The detection limit of the HPLC system employed in this study was approximately $10 \mathrm{ng}$ per injection. Thus, the 
injection volume of $50 \mu \mathrm{L}$ of analyte resulted in an absolute detection limit of $0.2 \mu \mathrm{g}$ MC-LR/mL analyte. As the MCLR concentrations (anti-Adda ELISA) that could be determined in the homogenates incubated with $1 \mu \mathrm{g} \mathrm{MC}-\mathrm{LR} / \mathrm{g}$ were far below the HPLC detection limit, it is not surprising that no MC-LR was detectable in these samples using HPLC.

Karlsson et al. (2003b) reported that matrix effects hindered HPLC-UV detection of nodularin in liver tissue samples of flounder, and Sipiä et al. (2001a) described HPLC as an inappropriate method for nodularin analysis in liver tissue samples using mobile and stationary phases with UV detection, as small concentrations $(\leq 0.3 \mu \mathrm{g}$ NOD/ $10 \mu \mathrm{L}$ injection) of nodularin easily escaped detection. Contrary to these findings, the present results suggest that HPLC-UV is an accurate analytical method for quantification of MC in tissue samples, as long as MC tissue contamination is greater than $0.2 \mu \mathrm{g}$ MC-LR/mL analyte, as specified by the sample treatment and extraction method used in this study.

Unspecific competitive background binding also was observed in the anti-Adda ELISA with control samples, representing less than $0.01 \mu \mathrm{g} \mathrm{MC}-\mathrm{LR} / \mathrm{mL}$ approximately. Sipiä et al. (2001a) described nodularin concentrations of less than $0.01 \mu \mathrm{g} / \mathrm{g}$ liver tissue to be below the level of quantification in MC-LR ELISA because of matrix effects. Kankaanpää et al. (2002a) described a level of nonspecific binding to antibodies of approximately $0.02 \mu \mathrm{g} \mathrm{MC} / \mathrm{g}$ liver tissue of sea trout analyzed for nodularin with MC-LR ELISA. Kankaanpää et al. (2005) also suggested that the theoretical detection limits of MC-LR ELISA for nodularin analysis in hepatopancreas and muscle tissue of prawns are affected by low-level matrix effects because of unspecific binding to and/or denaturing of the antibodies. Matrix effects in the analyses of nodularin in liver tissue samples of flounder also have been reported by Karlsson et al. (2003b), suggesting that analysis via MC-LR ELISA is not optimal if it is the only means of toxin analysis in tissue. In contrast, the results of the study reported here demonstrated that background/matrix-associated effects and thus the limit of detection in the anti-Adda ELISA employed were at least 30 times lower than in the CPPA and HPLC methods used. Moreover, in conjunction with the MC-LR amounts recovered from incubated homogenates in this study, overestimation of MC-LR contamination of tissue because of unspecific measurement by the anti-Adda ELISA appeared negligible.

In summary, when comparing the MC detection methods employed in this study and the results obtained with those previously reported, anti-Adda ELISA appears to be the most appropriate method for the detection of MC in tissue samples. In tissue samples contaminated with relatively high MC concentrations ( $>0.4 \mu \mathrm{g}$ MC-LR/g), both anti-Adda ELISA and HPLC-UV appear to be suitable methods for reliable MC detection in tissue samples. However, generally, a prerequisite for acceptable analyses is triplicate analyses and relevant standards and controls. The complementary use of different detection methods, that is, simultaneously using two or more analytical methods for the same analytes, is highly recommended, in agreement with other authors (Metcalf et al., 2000; Meriluoto, 2004), in order to achieve reliable detection of MC contamination in tissue samples.

Kankaanpää et al. (2002b) specified three possible reasons for incomplete recovery of nodularin and MC, as also observed in the study reported here: (i) loss during the analytical procedure, (ii) metabolism (conjugation) in tissue and, (iii) covalent binding of MC to macromolecules (proteins and peptides). One possible way to verify the abundance of MC-protein adducts is through immunoprobing using antibodies raised against MC or MC fragments, for example, the Adda moiety (Hitzfeld et al., 1999; Fischer and Dietrich, 2000; Mikhailov et al., 2003). As noncovalently bound MC-LR is expected to elute from a SDSPAGE denaturing gel, Adda-positive bands observed in the Western blots most likely represent MC-LR protein adducts in the liver homogenates analyzed. That cyanobacterial peptides such as nodularin, which do not appear to covalently bind to proteins, could not be detected in Western blots using the appropriate antibodies corroborates this (Mikhailov et al., 2003; Schmid et al., 2004). The presence of bands visible by anti-Adda immunostaining is therefore a distinct indication of the presence of covalently bound MC-LR adducts in incubated homogenates. This is in agreement with former studies, showing adducts in the 28to $38-\mathrm{kD}$ range that most likely represent PP-MC adducts to the liver endogenous protein phosphatases (Hitzfeld et al., 1999; Fischer and Dietrich, 2000; Ernst et al., 2001; Mikhailov et al., 2003). In agreement with the findings of previous investigations (Meriluoto, 1997; Williams et al., 1997a, 1997b; Amorim and Vasconcelos, 1999; Kankaanpää et al., 2002b), we observed loss in recovery that was probably attributable to irreversible covalent MC binding.

According to MacKintosh et al. (1990), the MC-binding capacity in mice liver is expected to be approximately $1 \mu \mathrm{g} / \mathrm{g}$. Similarly, Yoshida et al. (1998) estimated the amount of irreversibly bound $\mathrm{MC}$ in mice liver as $0.7 \mu \mathrm{g}$ $\mathrm{MC} / \mathrm{g}$ liver. Assuming a similar MC-binding capacity for fish, binding capacities may be expected also to be saturated for homogenates incubated with $1 \mu \mathrm{g} \mathrm{MC} / \mathrm{g}$. Consequently, MC recovery was only $1 \%-3 \%$ in homogenates incubated with $1 \mu \mathrm{g} \mathrm{MC} / \mathrm{g}$.

To extrapolate the above findings and conclusions to the routine situation of laboratory analyses of food samples and their safety assessment according to regulatory recommendations, the WHO recommendations and guidance values were employed in the analysis of the tissue levels used in this study in order to provide a reasonable example of risk calculation and extrapolation.

The WHO suggests a tolerable daily intake (TDI) of $0.04 \mu \mathrm{g} \quad \mathrm{MC}-\mathrm{LR}_{\text {equivalents }} / \mathrm{kg}$ food a day, where MC$\mathrm{LR}_{\text {equivalents }}$ is the sum of all MC congener concentrations 
TABLE V. Estimation of an interim maximum acceptable contamination (IMAC) for fish based on a tolerable daily intake of $0.04 \mu \mathrm{g} \mathrm{MC} / \mathrm{kg}$ bw, calculated based on average body weight of a $60 \mathrm{~kg}$, diverse average fish consumption (AFC) and various percentages of uptake of toxin (POT) via fish consumption

\begin{tabular}{clll}
\hline $\operatorname{AFC}(\mathrm{g} / \mathrm{d}) /$ POT $(\%)$ & \multicolumn{1}{c}{0.25} & \multicolumn{1}{c}{0.5} & 0.75 \\
\hline & & IMAC $[\mu \mathrm{g} / \mathrm{g}]$ & \\
10 & $0.060^{\mathrm{E}, \mathrm{H}}$ & $0.120^{\mathrm{E}, \mathrm{H}}$ & $0.180^{\mathrm{E}, \mathrm{H}}$ \\
50 & $0.012^{\mathrm{E}}$ & $0.024^{\mathrm{E}}$ & $0.036^{\mathrm{E}}$ \\
300 & 0.002 & 0.004 & 0.006 \\
\hline
\end{tabular}

\footnotetext{
${ }^{\mathrm{E}}$ Detectable using anti-Adda ELISA.

${ }^{\mathrm{H}}$ Detectable using HPLC.
}

likely to be in the food as contaminants. To determine an interim maximum acceptable concentration (IMAC) in fish used for consumption, the following equation was applied in accordance with the publication by Falconer (2001): $\mathrm{IMAC}=$ TDI $\times \mathrm{BW} \times \mathrm{POT} / \mathrm{AFC}$ where $\mathrm{BW}$ is body weight, POT is the proportion of toxin consumed in the form of contaminated fish, and AFC is the average fish consumption.

Average human body weight is assumed to be $60 \mathrm{~kg}$. Based on Egyptian and Brazilian eating habits, the AFC ranges from 100 to $300 \mathrm{~g}$ per day per person (Magalhaes et al., 2001; Mohamed et al., 2003). According to the European Commission (2004), worldwide fish consumption is calculated as $43 \mathrm{~g}$ per person per day (including fish from marine water, brackish water, and freshwater). People in Europe on average consume $67 \mathrm{~g}$ per person per day, ranging from $31 \mathrm{~g}$ in Austria to $167 \mathrm{~g}$ in Portugal. Average German fish consumption is $35 \mathrm{~g} /$ day. However, only $8 \mathrm{~g}$ of that is freshwater fish or fish from mildly saline waters, which are more likely to be affected by cyanobacterial blooms (http://europa.eu.int/comm/fisheries). Performing a universal risk assessment is difficult because of large differences in consumption and exposure conditions (high variation in AFC and POT). Consequently, guideline values for MC contamination of fish must be based on local customs, conditions, and circumstances.

Using various assumed AFC and POT levels, the interim maximum acceptable contamination for fish was calculated and demonstrated to vary between 0.002 and $0.18 \mu \mathrm{g} / \mathrm{g}$ tissue (Table V). Assuming detection limits in liver tissue (as demonstrated here) to be similar to that in muscle tissue, these IMACs were then compared to the three analytical methods used for MC-LR analysis in this study, from which it was determined that cPPA is generally inappropriate for $\mathrm{MC}$ tissue contamination analysis. Considering the relevant limits of detection, anti-Adda ELISA and HPLC may be used for certain IMACs (Table V). However, it also was clearly demonstrated that for providing safe and healthy food for consumers neither anti-Adda ELISA nor HPLC, depending on the AFC, is sufficiently sensitive to allow reliable detection and thus regulation of fish contaminated with MC (Table V). In addition, on the basis of the findings of MacKintosh et al. (1990), Yoshida et al. (1998), and the results reported here, it can be assumed that in tissue contaminated with concentrations of $\leq 1 \mu \mathrm{g} \mathrm{MC} / \mathrm{g}$, most $\mathrm{MC}$ is bound covalently.

In this respect, and given the unsatisfactory detection limits as mentioned above, further investigation and improvement of routinely applicable MC methods for fish tissue and/or food analyses are essential requirements for an effective risk assessment. Current investigations have demonstrated that such recent developments and improvements might include immunoaffinity chromatography, LCMS, and MALDI-TOF analyses (Hormazabal et al., 2000; Lawrence and Menard, 2001; Karlsson et al., 2003a, 2003b).

\section{REFERENCES}

Amorim A, Vasconcelos V. 1999. Dynamics of microcystins in the mussel Mytilus galloprovincialis. Toxicon 37:1041-1051.

Andersen RJ, Luu HA, Chen DZX, Holmes CFB, Kent ML, Le Blanc M, Taylor FJR, Williams DE. 1993. Chemical and biological evidence links microcystins to salmon 'netpen liver disease.' Toxicon 31:1315-1323.

Annadotter H, Cronberg G, Lawton L, Hansson HB, Göthe U, Skulberg O. 2001. An extensive outbreak of gastroenteritis associated with the toxic cyanobacterium Planktothrix agardhii (Oscillatoriales, Cyanophyceae) in Scania, South Sweden. In: Chorus I, editor. Cyanotoxins: occurrence, causes, consequences. Berlin: Springer. p 200-208.

Bradford MM. 1976. A rapid and sensitive method for the quantification of microgram quantities of protein utilizing the principle of protein-dye binding. Anal Biochem 72:248-254.

Briand JF, Jacquet S, Bernard C, Humbert JF. 2003. Health hazards for terrestrial vertebrates from toxic cyanobacteria in surface water ecosystems. Vet Res 34:361-377.

Byth S. 1980. Palm Island mystery disease. Med J Aust 2:40-42.

Chorus I, Falconer IR, Salas HJ, Bartram J. 2000. Health risk caused by freshwater cyanobacteria in recreational waters. J Toxicol Environ Health Part B 3:323-347.

Craig M, Luu HA, McCready TL, Williams D, Andersen RJ, Holmes C. 1996. Molecular mechanisms underlying the interaction of motuporin and microcystins with type- 1 and type-2A protein phosphatases. Biochem Cell Biol (Biochimie et Biologie Cellulaire) 74:569-578.

Dietrich DR, Hoeger SJ. 2005. Guidance values for microcystin in water and cyanobacterial supplement products (blue-green algae supplements): a reasonable or misguided approach? Toxicol Appl Pharmacol 203:273-289.

Eriksson JE, Meriluoto JAO, Lindholm T. 1989. Accumulation of a peptide toxin from the cyanobacterium Oscillatoria agardhii in the freshwater mussel Anodonta cygnea. Hydrobiologia 183:211-216. 
Ernst B, Hitzfeld BC, Dietrich DR. 2001. Presence of Planktothrix sp. and cyanobacterial toxins in Lake Ammersee, Germany and their impact on whitefish (Coregonus lavaretus L.). Environ Toxicol 16:483-488.

Falconer IR. 2001. Toxic cyanobacterial bloom problems in Australian waters: risk and impacts on human health. Phycologia 40:228-233.

Fischer WJ, Dietrich DR. 2000. Pathological and biochemical characterisation of microcystin-induced hepatopancreas and kidney damage in carp. Toxicol Appl Pharmacol 164:73-81.

Fischer WJ, Garthwaite I, Miles CO, Ross KM, Aggen JB, Chamberlin AR, Towers NR, Dietrich DR. 2001. Congener-independent immunoassay for microcystins and nodularins. Environ Sci Technol 35:4753-4757.

Heresztyn T, Nicholson BC. 2001. Determination of cyanobacterial hepatotoxins directly in water using a protein phosphatase inhibition assay. Water Res 35:3049-3056.

Hitzfeld BC, Fischer WJ, Eriksson JE, Mikhailov A, Dietrich DR. 1999. Immunochemical detection of microcystin-LR in tissues and cells of rainbow trout. Toxicol Sci 48:33.

Hormazabal V, Ostensvik O, Underdal B, Skulberg OM. 2000. Simultaneous determination of the cyanotoxins anatoxin a, microcystin desmethyl-3, LR, RR, and YR in fish muscle using liquid chromatography-mass spectrometry. J Liq Chromatogr Relat Technol 23:185-196.

Kankaanpää H, Holiday J, Schröder H, Godard TJ, Fister von R, Carmichael WW. 2005. Cyanobacteria in prawn farming in northern New South Wales, Australia - a case study on cyanobacteria diversity and hepatotoxin bioaccumulation. Toxicol Appl Pharmacol 203:243-256.

Kankaanpää H, Vuorinen PJ, Sipiä V, Keinänen M. 2002a. Acute effects and bioaccumulation of nodularin in sea trout (Salmo trutta m. trutta L.) exposed orally to Nodularia spumigena under laboratory conditions. Aquat Toxicol 61:155-168.

Kankaanpää HT, Vuorensola KM, Sipiä VO, Meriluoto JAO. 2002b. Chromatographic and spectral behaviour and detection of hepatotoxic nodularin in fish, clam, mussel and mouse tissues using HPLC analyses. Chromatographia 55: 157-162.

Karlsson K, Sipiä V, Kankaanpää H, Meriluoto J. 2003a. Mass spectrometric detection of nodularin and desmethylnodularin in mussels and flounders. J Chromatogr B 784:243-253.

Karlsson K, Sipiä V, Krause E, Meriluoto J, Pflugmacher S. 2003b. Mass spectrometry detection and quantification of nodularin-R in flounder livers. Environ Toxicol 18:284-288.

Laemmli U. 1970. Cleavage of structural proteins during assembly of the head of bacteriphage T4. Nature 227:680-685.

Landsberg JH. 2002. The effects of harmful algal blooms on aquatic organisms. Rev Fish Sci 10:245-254.

Lawrence JF, Menard C. 2001. Determination of blue green-algae, fish and water using liquid chromatography with ultraviolet detection after sample clean-up employing immunoaffinity chromatography. J Chromatogr 922:111-117.

Lawton LA, Edwards C, Codd GA. 1994. Extraction and high-performance liquid-chromatographic method for the determination of microcystins in raw and treated waters. Analyst 119:15251530 .
Liras V, Lindberg M, Nystrom P, Annadotter H, Lawton LA, Graf B. 1998. Can ingested cyanobacteria be harmful to the signal crayfish (Pacifastacus leniusculus). Freshw Biol 39:233-242.

MacKintosh C, Beattie KA, Klumpp S, Cohen P, Codd GA. 1990. Cyanobacterial microcystin-LR is a potent and specific inhibitor of protein phosphatases 1 and $2 \mathrm{~A}$ from both mammals and higher plants. FEBS Lett 264:187-192.

Magalhaes VF, Marinho MM, Domingos P, Oliviera AC, Costa SM, Azevedo LO, Azevedo SMFO. 2003. Microcystins (cyanobacteria hepatotoxins) bioaccumulation in fish and crustaceans from Sepetiba Bay (Brasil, RJ). Toxicon 42:289-295.

Magalhaes VF, Soares RM, Azevedo SM. 2001. Microcystin contamination in fish from the Jcarepaguá Lagoon (Rio de Janeiro, Brazil): ecological implication and human health risk. Toxicon 39:1077-1085.

Malbrouck C, Trausch G, Devos P, Kestemont P. 2003. Hepatic accumulation and effects of microcystin-LR on juvenile goldfish Carassius auratus L. Comp Biochem Physiol 135:39-48.

Malbrouck C, Trausch G, Devos P, Kestemont P. 2004. Effect of microcystin-LR on protein phosphatase activity in fed and fasted juvenile goldfish Carassius auratus L. Toxicon 43:295301.

Meriluoto J. 1997. Chromatography of microcystins. Anal Chim Acta 352:277-298.

Meriluoto J. 2004. Detection methods for cyanobacterial toxins. 6th International Conference on Toxic Cyanobacteria, Bergen, Norway. p 39.

Metcalf JS, Beattie KA, Pflugmacher S, Codd GA. 2000. Immuno-crossreactivity and toxicity assessment of conjugation products of the cyanobacterial toxin, microcystin-LR. FEMS Microbiol Lett 189:155-158.

Mikhailov A, Härmälä-Braskén AS, Hellman J, Meriluoto J, Eriksson JE. 2003. Identification of ATP-synthase as a novel intracellular target for microcystin-LR. Chemico-Biological Interactions 142:223-237.

Mohamed ZA, Carmichael WW, Hussein AA. 2003. Estimation of microcystin in the freshwater fish Oreochromis niloticus in an Egyptian fish farm containing a Microcystis bloom. Environ Toxicol 18:137-141.

Oliver CJ, Shenolikar S. 1998. Physiologic importance of protein phosphatase inhibitors. Front Biosci 3:D961-D972.

Pouria S, de Andrade A, Barbosa J, Cavalcanti R, Barreto V, Ward C, Preiser W, Poon G, Neild G, Codd G. 1998. Fatal microcystin intoxication in haemodialysis unit in Caruaru, Brazil. Lancet 352:21-26.

Prepas EE, Kotak BG, Campbell LM, Evans JC, Hrudey SE, Holmes CFB. 1997. Accumulation and elimination of cyanobacterial hepatotoxins by the freshwater clam Anodonta grandis simpsoniana. Can J Fish Aquat Sci 54:41-46.

Schmid D, Ernst B, Hoeger SJ, Dietrich DR. 2004. Characterisation and differentiation of two microcystin from Planktothrix spec. isolated from a pre-alpine lake in Europe. 6th International Conference on Toxic Cyanobacteria, Bergen, Norway. p 79.

Sipiä V, Kankaanpaa H, Lathi K, Carmichael WW, Meriluoto J. 2001a. Detection of nodularin in flounders and cod from the Baltic Sea. Environ Toxicol 16:121-126. 
Sipiä VO, Kankaanpää HT, Flinkmann J, Lahti K, Meriluoto JAO. 2001b. Time-dependent accumulation of cyanobacterial hepatotoxins in flounders (Platichthys flesus) and mussels (Mytilus edulis) from the Northern Baltic Sea. Environ Toxicol 16:330336.

Sivonen K, Jones G. 1999. Cyanobacterial toxins. In: Bartram J, editor. Toxic cyanobacteria in water. London: E \& FN Spon. $p$ 41-111.

Soares RM, Magalhaes VF, Azevedo SMFO. 2004. Accumulation and depuration of microcystins (cyanobacteria hepatotoxins) in Tilapia rendalli (Cichlidae) under laboratory conditions. Aquat Toxicol 70:1-10.

Teixeira M, Nascimento Costa M, Lucia Pires de Carvalho V, Santos Pereira M, Hage E. 1993. Gastroenteritis epidemic in the area of the Itaparica Dam, Bahia, Brazil. Bull PAHO 27:244253.

Tencalla F, Dietrich D. 1997. Biochemical characterization of microcystin toxicity in trout (Oncorhynchus mykiss). Toxicon 35:583-595.

Turner PC, Gammie AJ, Hollinrake K, Codd GA. 1990. Pneumonia associated with contact with cyanobacteria. $\mathrm{Br}$ Med J 300:1440-1441.

Williams DE, Craig M, Dawe SC, Kent ML, Andersen RJ, Holmes CFB. 1997a. ${ }^{14}$ C-labeled microcystin-LR administered to Atlantic salmon via intraperitoneal injection provides In vivo evidence for covalent binding of microcystin-LR in salmon livers. Toxicon 35:985-989.

Williams DE, Craig M, Dawe SC, Kent ML, Holmes CFB, Andersen RJ. 1997b. Evidence for a covalently bound form of microcystin-LR in salmon liver and dungeness crab larvae. Chem Res Toxicol 10:463-469.

Williams DE, Dawe SC, Kent ML, Andersen RJ, Craig M, Holmes CFB. 1997c. Bioaccumulation and clearance of microcystis from salt water mussels, Mytilus edulis, and in vivo evidence for covalently bound microcystin in mussel tissues. Toxicon 35:1617-1625.

Williams DE, Kent ML, Andersen RJ, Klix H, Holmes CFB. 1995. Tissue distribution and clearance of tritium-labeled dihydromicrocystin-LR epimers administered to Atlantic salmon via intraperitoneal injection. Toxicon 33:125-131.

Yoshida T, Makita Y, Tsutsumi T, Nagata S, Tashiro F, Yoshida F, Sekuima M, Tamura SI, Harada T, Mata K, Ueno Y. 1998. Immunohistochemical localisation of microcystin-LR in the liver of mice: A study on the pathogenesis of microcystin-LR induced hepatotoxicity. Environ Toxicol Pathol 26:411-418.

Yu S-Z. 1995. Primary prevention of hepatocellular carcinoma. J Gastroenterol Hepatol 10:674-682.

Zhou L, Yu H, Chen K. 2002. Relationship between microcystin in drinking water and colorectal cancer. Biomed Environ Sci 15:166-171. 